\title{
PENGARUH KOMPETENSI DAN PELATIHAN TERHADAP KINERJA PEGAWAI PADA DINAS TENAGA KERJA DAN TRANSMIGRASI KABUPATEN KARAWANG
}

Oleh :

\begin{tabular}{|c|c|}
\hline \multicolumn{2}{|c|}{$\begin{array}{c}\text { Aditya Batistuta Maulana, } \\
\text { Fakultas Ekonomi, Universitas Singaperbangsa Karawang } \\
\text { Email : adityabatistuta14@ gmail.com } \\
\text { Cecep Hermana, } \\
\text { Fakultas Ekonomi, Universitas Singaperbangsa Karawang } \\
\text { Email : chermana911@ @staff.unsika.ac.id }\end{array}$} \\
\hline Article Info & Abstract \\
\hline $\begin{array}{l}\text { Article History : } \\
\text { Received } 30 \text { March }-2021 \\
\text { Accepted } 14 \text { Sept }-2021 \\
\text { Available Online } 25 \text { Sept - } \\
2021\end{array}$ & $\begin{array}{l}\text { This study aims to determine the effect of competence and training } \\
\text { on employee performance at the Manpower and Transmigration } \\
\text { Office, Karawang regency. The research method used is descriptive } \\
\text { verification with a quantitative approach. The research sample was } \\
100 \text { employees, using nonprobability sampling. The analysis used } \\
\text { is path analysis and hypothesis testing using the test and F test. } \\
\text { The results of this study indicate that there is a correlation between } \\
\text { competence and training of } 0.864 \text {, which means that there is a } \\
\text { strong relationship. The results of the partial hypothesis test } \\
\text { Competence have a positive and significant effect on employee } \\
\text { performance, training has a positive and significant effect on } \\
\text { employee performance. The simultaneous hypothesis results of } \\
\text { competence and training simultaneously have a significant effect } \\
\text { on employee performance. } R^{2} \text { test for Competency and Training on } \\
\text { Employee Performance obtained } R \text { Square of } 0.923 \text {, meaning that } \\
92.3 \% \text { of employee performance is influenced by these two } \\
\text { variables, while } 7.9 \% \text { of employee performance is influenced by } \\
\text { other variables not examined in this study. }\end{array}$ \\
\hline $\begin{array}{l}\text { Keyword: } \\
\text { Competence, Training, } \\
\text { Employee Performance. }\end{array}$ & \\
\hline
\end{tabular}

\section{PENDAHULUAN}

Dalam menghadapi era globalisasi di Indonesia, organisasi swasta maupun pemerintahan dituntut untuk terus berinovasi, guna menghadapi tuntutan kemajuan serta perubahan zaman. Berhasil atau tidaknya suatu organisasi dalam membuat suatu inovasi-inovasi baru tergantung pada keberhasilan dari sumber daya manusia organisasi tersebut dalam menjalankan tugasnya. Keberadaan sumber daya manusia yang handal memiliki peran yang strategis di dalam sebuah organisasi. Sumber
Daya Manusia adalah harta yang paling penting yang dimiliki oleh suatu organisasi, sedangkan manajemen yang efektif adalah kunci bagi keberhasilan suatu organisasi tersebut.

Ketenagakerjaan menjadi penting untuk diketahui, baik bagi tenaga kerja maupun bagi perusahaan sebagai pemberi kerja. Di dalam pertimbangan undang-undang Nomor 13 Tahun 2003 tentang ketenagakerjaan dinyatakan bahwa dalam pelaksaan pembangunan nasional, tenaga kerja mempunyai peranan dan kedudukan yang sangat penting sebagai pelaku dan tujuan 
pembangunan. Ketenagakerjaan merupakan segala hal yang berhubungan dengan tenaga kerja pada waktu sebelum dan sesudah masa kerja.

Sumber daya manusia yang di miliki dalam suatu organisasi sangat berpengaruh untuk kemajuan dan perkembangan organisasi. Maka dari pada itu sumber daya manusia merupakan salah satu masalah pokok yang dihadapi oleh bangsa Indonesia khususnya di kabupaten Karawang sebagai kabupaten yang sedang gencar-gencarnya melakukan pembangunan.

Dinas Tenaga Kerja dan Transmigrasi Kabupaten Karawang (DISNAKERTRANS) organisasi yang bergerak dalam bidang ketenagakerjaan dan transmigrasi di Kabupaten Karawang. Dinas Tenaga Kerja dan Transmigrasi Kabupaten Karawang diatur dalam Peraturan Bupati Karawang nomor 49 tahun 2016 tentang kedudukan, susunan organisasi, tugas, fungsi dan tata kerja Dinas Ketenagakerjaan dan Transmigrasi Kabupaten Karawang. Dinas Tenaga Kerja dan Transmigrasi Kabupaten Karawang mempunyai tugas pokok membantu Bupati dalam melaksanakan sebagian urusan pemerintah daerah dibidang ketenagakerjaan dan transmigrasi serta tugas pembantuan yang ditugaskan kepada pemerintah daerah.

Dengan adanya tugas pokok yang dijalankan, tentu para pegawai di Dinas Tenaga Kerja dan Tranmigrasi Kabupaten Karawang juga melaksanakan tugas-tugas atau jobdesc yang ada dalam organisasai tersebut, terlepas dari tugas pokok yang sudah ada. Dengan demikian, untuk menjalankan tugas tersebut perlu perilaku kerja yang baik untuk menunjang dan meningkatkan hasil kerja yang dijalankan.

Penetapan kompetensi dalam organisasi dapat memperjelas standar kerja dan tujuan yang ingin dicapai serta dapat mengomunikasikan nilai dan hal-hal yang harus menjadi fokus kerja Pegawai. Terlebih selama ini banyak instansi pemerintah yang belum mempunyai pegawai dengan kompetensi yang memadai, ini dibuktikan dengan rendahnya produktivitas pegawai dan sulitnya mengukur kinerja pegawai, Slamet Riyadi (2008:18). Oleh karena itu diperlukan adanya pelaksanakan identifikasi kompetensi yang relevan dan bertujuan untuk meningkatkan kinerja SDM, agar memungkinkan kelangsungan hidup organisasi mencapai keberhasilan kompetitif, Bophy dan Kiely dalam Nadia Karina (2017:4).

Identifikasi Kompetensi Pegawai selain dapat dilihat dari segi Tingkat pendidikan tiap pegawai yang bekerja pada organisasi, tapi juga dapat diketahui dari segi keterampilan dan pengetahuan. Dalam rangka meningkatkan Kinerja dan meningkatkan kompetensi pegawai, Organisasi perlu melaksanakan Pelatihan kerja bagi setiap Pegawai dengan peran dan fungsi masing - masing Divisi atau bagian kerja. Pelatihan meerupakan salah satu upaya untuk meningkatkan kinerja pegawai secara optimal, dengan demikian perlu dulakukan usaha peningkatan mutu dan kualitas sumber daya manusia dengan mengadakan pengembangan pegawai.

Pelatihan adalah upaya yang direncanakan oleh suatu perusahaan untuk mempermudah pembelajaran para Pegawai tentang kompetensikompetensi yang berkaitan dengan pekerjaan. Kompetensi tersebut meliputi pengetahuan, keterampilan, dan perilaku-perilaku yang sangat penting atau berpengaruh langsung terhadap kinerja Pegawai. Sasaran pelatihan bagi Pegawai adalah menguasai pengetahuan, keterampilan, dan perilaku yang ditekankan pada programprogram pelatihan serta menerapkannya kedalam aktivitas-aktivitas sehari-hari. Raymond A. Noe, dalam Ilman Ataunur dan Eny Ariyanto (2015:138)

\section{KAJIAN PUSTAKA DAN PENGEMBANGAN HIPOTESIS Kompetensi}

Menurut Edison yang dikutip oleh Yuliana (2017:136), Kompetensi adalah kemampuan individu untuk melaksanakan suatu pekerjaan dengan benar dan memiliki keunggulan yang didasarkan pada hal-hal yang menyangkut pengetahuan (knowledge), keahlian (skill), dan sikap (attitude).

Berkaitan dengan pemahaman mengenai kompetensi sebagai underlying characteristic seseorang, Spencer, Lyle M. and Signe M. Spencer (2011:72-74) menyebutkan ada lima 
jenis karakteristik kompetensi. Kelimanya adalah sebagai berikut:

a. Motives. Sesuatu secara konsisten dipikirkan yang menyebabkan seseorang bertindak. Motives mampu menggerakkan, mengarahkan, dan memilih perilaku menuju kepada tindakan tertentu atau kepada tujuan. Orang- orang yang termotivasi untuk mencapai sesuatu secara konsisten membuat sasaran yang menantang untuk dirinya sendiri, bertanggungjawab untuk menyelesaikannya, dan menggunakan umpan balik untuk melakukannya dengan lebih baik

b. Traits. Merupakan karaktristik fisik dan respon yang konsisten terhadap situasi dan informasi. Spencer dan Spencer mencontohkan karakteristik ini dengan pilot pesawat tempur yang memilki reaksi waktu dan penglihatan yang baik. Begitu pula dengan kompleksnya mengontrol emosi sendiri dan berinisiatif sebagai bentuk respon-respon yang harus konsisten pada setiap situasi.

c. Self concept. Karakteristik ini menitikberatkan pada sikap-sikap seseorang, nilai-nilai yang dianut/dipegang, atau citra diri. Seseorang yang memiliki kepercayaan diri akan membuat orang tersebut efektif di hampir situasi apapun.

d. Knowledge. menginformasikan bahwa seseorang memiliki kadar pada bidangbidang khusus. Misalnya, pengetahuan ahli bedah terhadap syaraf dan otot di dalam tubuh manusia. Spencer dan Spencer menegaskan bahwa skor-skor tes pengetahuan sering gagal untuk memprediksikan kinerja karena skor-skor tersebut gagal untuk mengukur pengetahuan dan keterampilan yang sebenarnya digunakan dalam bekerja

e. Skill. Kemampuan untuk melaksanakan tugas-tugas fisik tertentu atau yang berhubungan dengan tugas-tugas memerlukan pikiran.

\section{Pelatihan}

Menurut Hasibuan (2013:81), pelatihan adalah suatu metode pendidikan yang dilakukan dengan cara mengajarkan keahlian dan keterampilan kerja tertentu kepada pegawai.
Anwar Prabu Mangkunegara (2011:48), ada beberapa indikator pelatihan.Adapun Indikator pelatihan tersebut antara lain adalah :

a. Instruktur Mengingat pelatih umumnya berorientasi pada peningkatan skill,maka para pelatih dipilih untuk memberikan materi pelatihan harus benar-benar memiliki kualitas yang memadai sesuai bidangnya,personal dan kompeten, selain itu pendidikan instruktur pun harus benar-benar baik untuk melakukan pelatihan.

b. Peserta

Peserta pelatihan harus diseleksi berdasarkan persyaratan tertentu dan kualifikasi yang sesuai, selain itu peserta pelatihan juga harus memiliki semangat yang tinggi untuk mengikuti pelatihan.

c. Materi

Pelatihan sumber daya manusia merupakan materi atau kurikulum yang sesuai dengan tujuan pelatihan sumber daya manusia yang hendak dicapai oleh perusahaan dan materi pelatihan pun harus update agar si peserta dapat memahami masalah yang terjadi pada kondisi yang sekarang.

d. Metode

Metode pelatihan akan lebih menjamin berlangsungnya kegiatan pelatihan sumber daya manusia yang effektif apabila sesuai dengan jenis materi dan komponen peserta pelatihan.

e. Tujuan

Pelatihan merupakan tujuan yang ditentukan, khususnya terkait dengan penyusunan rencana aksi dan penetapan sasaran, serta hasil yang diharapkan dari pelatihan yang akan diselenggarakan, selain itu tujuan pelatihan pula harus disosialisasikan sebelumnya pada para peserta dapat memahami pelatihan tersebut.

f. Sasaran

Sasaran pelatihan harus ditentukan dengan kriteria yang terinci dan terukur.

\section{Kinerja Pegawai}

Menurut Mangkunegara yang dikuip oleh Anggi Dyah Ayu, dkk (2014:3) prestasi kerja atau kinerja adalah hasil kerja secara kualitas dan kuantitas yang dicapai oleh seorang 
pegawai dalam melaksanakan tugasnya sesuai dengan tanggung jawab yang diberikan kepadanya.

Menurut John Miner dalam buku Sudarmanto yang berjudul kinerja dan pengembangan kompetensi SDM (2014:11) bahwa dimensi yang dijadikan tolak ukur dalam menilai kinerja adalah sebagai berikut :

a. Kualitas, yaitu: tingkat kesalahan dalam proses bekerja, kerusakan yang terjadi akibat kesalahan pegawai, dan kecermatan pegawai dalam melakukan dan melaksanakan pekerjaannya.

b. Kuantitas, yaitu: hasil pekerjaan dari apa yang telah dilakukan oleh pegawai.

c. Penggunaan waktu dalam bekerja, yaitu : tingkat ketidakhadiran pegawai, keterlambatan pegawai, efektifitas waktu dalam melakukan pekerjaan.

d. Kejasama, yaitu: saling membantu dalam melakukan tugas atau pekerjaan, koordinasi antar setiap pegawai dan atasan, kerja tim dengan orang lain dalam bekerja.

\section{Hipotesis Penelitian}

\section{Korelasi antara Kompetensi dengan Pelatihan}

$\mathrm{H}_{\mathrm{o}}: \mathrm{rX}_{1} \mathrm{X}_{2}=0$ Tidak terdapat korelasi antara Kompetensi dengan Pelatihan

$\mathrm{Ha}: \mathrm{rX}_{1} \mathrm{X}_{2} \neq 0$ Terdapat korelasi antara Kompetensi dengan Pelatihan

\section{Pengaruh Secara Parsial Kompetensi terhadap Kinerja Pegawai}

$\mathrm{H}_{\mathrm{o}}=\rho \mathrm{y} \mathrm{X}_{1}=0$ Kompetensi tidak berpengaruh secara parsial terhadap Kinerja Pegawai Dinas tenaga Kerja dan transmigrasi Kabupaten Karawang.

$\mathrm{Ha}=\rho y \mathrm{X}_{1} \neq 0$ Kompetensi berpengaruh secara parsial terhadap Kinerja Pegawai Dinas tenaga Kerja dan transmigrasi Kabupaten Karawang.

\section{Pengaruh Secara Parsial Pelatihan terhadap kinerja Pegawai}

$\mathrm{H}_{\mathrm{o}}=\rho \mathrm{y} \mathrm{X}_{2}=0$ Pelatihan tidak berpengaruh secara parsial terhadap Kinerja Pegawai Dinas tenaga Kerja dan transmigrasi Kabupaten Karawang.
$\mathrm{Ha}=\rho \mathrm{y} \mathrm{X}_{2} \neq 0$ Pelatihan berpengaruh secara parsial terhadap Kinerja Pegawai Dinas tenaga Kerja dan transmigrasi Kabupaten Karawang.

\section{Pengaruh Simultan Kompetensi dan Pelatihan terhadap Kinerja Pegawai}

$\mathrm{H}_{\mathrm{o}}$ : $\rho \mathrm{y} \mathrm{X}_{1} ; \rho \mathrm{y} \mathrm{X}_{2} ; \rho \mathrm{y} \mathrm{X}_{1} \mathrm{X}_{2}=0$ Kompetensi dan Pelatihan secara simultan tidak berpengaruh terhadap Kinerja Pegawai Dinas tenaga Kerja dan transmigrasi Kabupaten Karawang.

$\mathrm{H}_{\mathrm{o}}$ : $\rho \mathrm{y} \mathrm{X}_{1} ; \rho \mathrm{y} \mathrm{X}_{2} ; \rho \mathrm{y} \mathrm{X}_{1} \mathrm{X}_{2} \neq 0$ Kompetensi dan Pelatihan secara bersama berpengaruh terhadap Kinerja Pegawai Dinas tenaga Kerja dan transmigrasi Kabupaten Karawang.

\section{METODE PENELITIAN}

Metode penelitian yang digunakan dalam penelitian ini adalah metode deskriptif verifikatif yang dilaksanakan melalui pengumpulan data di lapangan menggunakan alat bantu Spps 16 . Variabel Kompetensi (X1) dan Kompetensi $\left(\mathrm{X}_{2}\right)$ sebagai variable independent dan Kinerja Pegawai (Y) sebagai variabel dependent. Jenis data yang digunakan peneliti dalam penelitian ini yaitu data primer dan sekunder. Sampel penelitian sebanyak 100 pegawai pada dinas tenaga Kerja dan Transmigrasi Kabupaten Karawang dengan menggunakan teknik nonprobability sampling. Adapun analisis yang digunakan adalah analisis jalur (Path Analysis).

\section{HASIL DAN PEMBAHASAN}

\section{Analisi Deskriptif}

Tabel 1 Rekapitulasi Variabel Kompetensi $\left(\mathbf{X}_{1}\right)$

\begin{tabular}{|c|l|c|c|}
\hline No & \multicolumn{1}{|c|}{ Indikator } & $\begin{array}{c}\text { Skor } \\
\text { Total }\end{array}$ & Kategori \\
\hline 1 & $\begin{array}{l}\text { Orientasi Pada } \\
\text { Pencapaian Tugas }\end{array}$ & 380 & Setuju \\
\hline 2 & Dampak dan Pengaruh & 371 & Setuju \\
\hline 3 & Inisiatif & 360 & Setuju \\
\hline 4 & $\begin{array}{l}\text { Bekerjasama dengan } \\
\text { Tim }\end{array}$ & 340 & $\begin{array}{l}\text { Cukup } \\
\text { Setuju }\end{array}$ \\
\hline 5 & $\begin{array}{l}\text { Membangun } \\
\text { Kebersamaan }\end{array}$ & 327 & $\begin{array}{l}\text { Cukup } \\
\text { Setuju }\end{array}$ \\
\hline
\end{tabular}




\begin{tabular}{|c|l|c|c|}
\hline No & \multicolumn{1}{|c|}{ Indikator } & $\begin{array}{c}\text { Skor } \\
\text { Total }\end{array}$ & Kategori \\
\hline 6 & Percaya Diri & 377 & Setuju \\
\hline 7 & Kontrol Diri & 363 & Setuju \\
\hline 8 & $\begin{array}{l}\text { Senantiasa mencari } \\
\text { informasi }\end{array}$ & 361 & Setuju \\
\hline 9 & Keahlian teknis & 337 & $\begin{array}{c}\text { Cukup } \\
\text { Setuju }\end{array}$ \\
\hline 10 & Berpikir analisis & 341 & Setuju \\
\hline 11 & Berpikir konseptual & 353 & Setuju \\
\hline \multicolumn{2}{|c|}{ Total } & \multicolumn{2}{|c|}{3910} \\
\hline \multicolumn{2}{|c|}{ Mean } & \multicolumn{2}{|c|}{201010} \\
\hline
\end{tabular}

Sumber : Data yang diolah peneliti, 2021

Berdasarkaan tabel di atas, Total Skor untuk variabel Kompetensi sebesar 3910 dan rata - rata sebesar 355,4 dengan kriteia rentang skala sampel responden Kompetensi Pegawai Dinas tenaga Kerja dan Transmigrasi Kabupaten Karawang secara umum berada pada kriteria setuju. Artinya pegawai setuju bahwa Kompetensi Pegawai Dinas Tenaga Kerja dan Transmigrasi Kabupaten Karawang sudah baik.

\section{Tabel 2 Rekapitulasi Variabel Pelatihan $\left(\mathbf{X}_{2}\right)$}

\begin{tabular}{|c|l|c|c|}
\hline No & \multicolumn{1}{|c|}{ Indikator } & $\begin{array}{l}\text { Skor } \\
\text { Total }\end{array}$ & Kategori \\
\hline 1 & $\begin{array}{l}\text { Cara penyampaian } \\
\text { materi }\end{array}$ & 380 & Setuju \\
\hline 2 & $\begin{array}{l}\text { Instruktur dari luar } \\
\text { perusahaan }\end{array}$ & 367 & Setuju \\
\hline 3 & Kualifikasi peserta & 348 & Setuju \\
\hline 4 & $\begin{array}{l}\text { Mekanisme pemilihan } \\
\text { peserta }\end{array}$ & 371 & Setuju \\
\hline 5 & Materi ringkas & 371 & Setuju \\
\hline 6 & $\begin{array}{l}\text { Materi sesuai dengan } \\
\text { kebutuhan }\end{array}$ & 361 & Setuju \\
\hline 7 & $\begin{array}{l}\text { Metode sudah sesuai } \\
\text { dengan standarisasi }\end{array}$ & 384 & Setuju \\
\hline 8 & $\begin{array}{l}\text { Metode disukai oleh } \\
\text { peserta }\end{array}$ & 377 & Setuju \\
\hline 9 & Peningkatan Kinerja & 360 & Setuju \\
\hline 10 & $\begin{array}{l}\text { Peningkatan } \\
\text { Keterampilan dan } \\
\text { keahlian }\end{array}$ & 340 & $\begin{array}{l}\text { Cukup } \\
\text { Setuju }\end{array}$ \\
\hline 11 & $\begin{array}{l}\text { Pegawai yang kurang } \\
\text { memiliki keterampilan }\end{array}$ & 372 & Setuju \\
\hline 12 & Sasaran jelas & 360 & Setuju \\
\hline & Total & \multicolumn{2}{|c|}{36591} \\
\hline
\end{tabular}

Sumber : Data yang diolah peneliti, 2021

Berdasarkaan tabel di atas, Total Skor untuk variabel Pelatihan sebesar 3910 dan rata - rata sebesar 365,9 dengan kriteia rentang skala sampel responden Pelatihan Pegawai pada Dinas tenaga Kerja dan Transmigrasi Kabupaten Karawang secara umum berada pada kriteria setuju. Artinya responden setuju bahwa Pelatihan Pegawai yang telah diselenggarakan oleh Dinas Tenaga Kerja dan Transmigrasi Kabupaten Karawang sudah baik.

\section{Tabel 3 Rekapitulasi Variabel Kinerja} Pegawai (Y)

\begin{tabular}{|c|l|c|c|}
\hline No & \multicolumn{1}{|c|}{ Indikator } & $\begin{array}{c}\text { Skor } \\
\text { Total }\end{array}$ & Kategori \\
\hline 1 & Tingkat kesalahan & 365 & Setuju \\
\hline 2 & Tingkat kerusakan & 360 & Setuju \\
\hline 3 & Kecermatan & 348 & Setuju \\
\hline 4 & $\begin{array}{l}\text { Jumlah hasil } \\
\text { pekerjaan }\end{array}$ & 366 & Setuju \\
\hline 5 & $\begin{array}{l}\text { Tingkat } \\
\text { ketidakhadiran }\end{array}$ & 364 & Setuju \\
\hline 6 & Keterlambatan & 353 & Setuju \\
\hline 7 & Efektifitas kerja & 377 & Setuju \\
\hline 8 & Kerja tim & 371 & Setuju \\
\hline 9 & $\begin{array}{l}\text { Komunikasi antar } \\
\text { pegawai }\end{array}$ & 337 & $\begin{array}{l}\text { Cukup } \\
\text { Setuju }\end{array}$ \\
\hline 10 & Saling membantu & 343 & Setuju \\
\hline \multicolumn{2}{|c|}{ Total } & \multicolumn{2}{|c|}{3584} \\
\hline \multicolumn{2}{|c|}{ Mean } & \multicolumn{2}{|c|}{} \\
\hline
\end{tabular}

Sumber : Data yang diolah peneliti, 2020

Berdasarkaan tabel di atas, Total Skor untuk variabel Kinerja Pegawai sebesar 3584 dan rata rata sebesar 358,4 dengan kriteria rentang skala sampel responden Kinerja Pegawai pada Dinas tenaga Kerja dan Transmigrasi Kabupaten Karawang secara umum berada pada kriteria setuju. Artinya pegawai setuju bahwa Kinerja Pegawai atau Hasil Kerja Pegawai Dinas Tenaga Kerja dan Transmigrasi Kabupaten Karawang sudah baik. 


\section{Analisis Verifikatif}

Tabel 5 Pengaruh Simultan Kompensasi $\left(\mathrm{X}_{1}\right)$ dan Pelatihan $\left(\mathrm{X}_{2}\right)$ terhadap Kinerja Pegawai (Y)

\begin{tabular}{|c|c|c|c|c|c|}
\hline \multirow[t]{2}{*}{$\begin{array}{c}\text { Varia } \\
\text { bel }\end{array}$} & \multirow{2}{*}{$\begin{array}{c}\text { Koefisi } \\
\text { en } \\
\text { jalur }\end{array}$} & \multirow{2}{*}{$\begin{array}{c}\text { Pengar } \\
\text { uh } \\
\text { langsu } \\
\text { ng }\end{array}$} & \multicolumn{2}{|c|}{$\begin{array}{c}\text { Pengaruh } \\
\text { Tidak } \\
\text { Langsung }\end{array}$} & \multirow{2}{*}{$\begin{array}{c}\text { Subtot } \\
\text { al } \\
\text { Pengar } \\
\text { uh }\end{array}$} \\
\hline & & & $\mathbf{X}_{1}$ & $\mathbf{X}_{2}$ & \\
\hline $\mathrm{X}_{1}$ & 0,381 & 0,145 & & $\begin{array}{c}0,20 \\
1\end{array}$ & 0,346 \\
\hline $\mathrm{X}_{2}$ & 0,612 & 0,374 & $\begin{array}{c}0,2 \\
01\end{array}$ & & 0,575 \\
\hline \multicolumn{5}{|c|}{ Total } & 0,921 \\
\hline \multicolumn{5}{|c|}{ Kontribusi Variabel lain $(\varepsilon)=1-0,921$} & 0,079 \\
\hline
\end{tabular}

Sumber : Data yang diolah peneliti, 2021

Pada Tabel 4 menunjukan bahwa total pengaruh yang disebabkan Kompetensi $\left(\mathrm{X}_{1}\right)$ dan Pelatihan $\left(\mathrm{X}_{2}\right)$ Terhadap Kinerja Pegawai $(\mathrm{Y})$ yaitu sebesar 0,921 atau $92,1 \%$. Adapun pengaruh lain diluar model adalah sebesar $1-0,921=0,079$ atau $7,9 \%$.

Tabel 5 Koefisien Determinasi

\begin{tabular}{|l|r|r|r|r|}
\hline \multicolumn{5}{|c|}{ Model Summary } \\
\hline $\begin{array}{c}\text { Mode } \\
1\end{array}$ & $\mathrm{R}$ & $\begin{array}{c}\mathrm{R} \\
\text { Square }\end{array}$ & $\begin{array}{c}\text { Adjusted R } \\
\text { Square }\end{array}$ & $\begin{array}{r}\text { Std. Error of } \\
\text { the Estimate }\end{array}$ \\
\hline 1 & $.961^{\mathrm{a}}$ & .923 & .921 & 1.21330 \\
\hline \multicolumn{4}{|l}{ a. Predictors: (Constant), X2, X1 } \\
\hline
\end{tabular}

\section{Sumber : Hasil Pengolahan Data SPSS 16} ,diolah peneliti, 2021

Berdasarkan tabel 5 menunjukan bahwa Koefisien Determinasi $\left(\mathrm{R}^{2}\right)$ Sebesar 0,921, berarti 92,1. Variabel Kinerja (Y) bisa diterangkan oleh variabel Kompetensi $\left(\mathrm{X}_{1}\right)$ dan Pelatihan $\left(\mathrm{X}_{2}\right)$ atau dapat diartikan Kompetensi dan Pelatihan $\left(\mathrm{X}_{2}\right)$ memiliki kontribusi Terhadap Kinerja Sebesar $92,1 \%$, sedangkan sisanya $7,9 \%$ merupakan Kontribusi Variabel lain $(\varepsilon)$ yang tidak diteliti.

\section{Hasil Uji Hipotesis}

\section{Korelasi Antara Kompetensi $\left(\mathbf{X}_{1}\right)$ dan Pelatihan $\left(\mathbf{X}_{2}\right)$}

Pengujian Hipotesis hubungan antara Kompetensi $\left(\mathrm{X}_{1}\right)$ dan Pelatihan $\left(\mathrm{X}_{2}\right)$ dilakukan dengan uji statistik $t$, yaitu dengan rumus sebagai berikut :

$$
t=\frac{r \sqrt{n-2}}{\sqrt{1-r^{2}}}
$$

Diketahui : $\quad r=0,864$

$$
\mathrm{N}=100
$$

Maka :

$$
\begin{aligned}
& t=\frac{0,864 \sqrt{100-2}}{\sqrt{1-(0,864)^{2}}} \\
& t=\frac{0,864(9,899)}{\sqrt{1-0,746}} \\
& t=\frac{8,552}{0,503} \\
& t=17,001
\end{aligned}
$$

Nilai thitung atau selanjutnya dibandingkan dengan $t_{\text {tabel }}$ pada tingkat kesalahan $5 \% \mathrm{db}=\mathrm{n}-2=100-2=98$, maka diperoleh $\mathrm{t}_{\text {tabel }}=1,66055$. Dengan demikian diketahui $\mathrm{t}_{\text {hitung }}$ $(17,001)>t_{\text {tabel }}(1,66055)$, maka dapat dinyatakan bahwa $\mathrm{H}_{\mathrm{O}}$ ditolak, artinya ada hubungan yang signifikan antara Kompetensi $\left(\mathrm{X}_{1}\right)$ dan Pelatihan $\left(\mathrm{X}_{2}\right)$.

\section{Hipotesis Pengaruh Variabel Secara Parsial}

Tabel 6 Pengaruh Parsial Kompetensi $\left(\mathrm{X}_{1}\right)$ Terhadap Kinerja Pegawai (Y)

\begin{tabular}{|c|c|c|c|c|c|}
\hline Struktur & Sig. & $\boldsymbol{\alpha}$ & $\mathbf{t}_{\text {hitung }}$ & $\mathbf{t}_{\text {tabel }}$ & Kesimpulan \\
\hline Pyx $_{1}$ & 0.000 & 0.05 & 6,811 & 1,66055 & Ho ditolak \\
\hline
\end{tabular}

\section{Sumber : Data yang diolah peneliti, 2021}

Berdasarkan Tabel 4.52 dapat dilihat bahwa sig. $(0.000)<\alpha(0.05)$ dan $t_{\text {hitung }}=6,811>t_{\text {tabel }}=$ 1,66055, maka $\mathrm{H}_{\mathrm{o}}$ ditolak. Dengan demikian dapat disimpulkan bahwa Kompetensi berpengaruh parsial terhadap Kinerja Pegawai.

Tabel 7 Pengaruh Parsial Pelatihan $\left(\mathbf{X}_{2}\right)$ Terhadap Kinerja Pegawai (Y)

\begin{tabular}{|c|c|c|c|c|c|}
\hline Struktur & Sig. & $\mathbf{A}$ & $\mathbf{t}_{\text {hitung }}$ & $\mathbf{t}_{\text {tabel }}$ & Kesimpulan \\
\hline Pyx $_{2}$ & 0.000 & 0.05 & 10,936 & 1,66055 & Ho ditolak \\
\hline
\end{tabular}

Sumber : Data yang diolah peneliti, 2021 
Berdasarkan Tabel 4.53 dapat dilihat bahwa sig. $(0.000)<\alpha(0.05)$ dan $t_{\text {hitung }}=10,936>t_{\text {tabel }}=$ 1,66055, maka $\mathrm{H}_{\mathrm{O}}$ ditolak. Dengan demikian dapa t disimpulkan bahwa Pelatihan berpengaruh parsial terhadap Kinerja Pegawai.

\section{Hipotesis Pengaruh Variabel Secara Simultan}

Untuk Kompetensi $\left(\mathrm{X}_{1}\right)$ dan Pelatihan $\left(\mathrm{X}_{2}\right)$ secara simultan Terhadap Kinerja Pegawai (Y) dengan tingkat signifikan $(\alpha)=5 \%$, degree of freedom $(\mathrm{df})=\mathrm{n}-2=100-2=98$ Diperoleh $\mathrm{t}_{\text {tabel }}$ $=1,66055$, sedangkan $\mathrm{f}_{\text {tabel }}=3,94$, kemudian $\mathrm{f}_{\text {hitung }}$ dapat dilihat pada tabel berikut :

Tabel 8 Hasil Perhitungan Nilai F

\begin{tabular}{|c|c|c|c|c|c|c|}
\hline \multicolumn{7}{|c|}{ ANOVA $^{a}$} \\
\hline \multicolumn{2}{|c|}{ Model } & $\begin{array}{l}\text { Sum of } \\
\text { Squares }\end{array}$ & Df & $\begin{array}{c}\text { Mean } \\
\text { Square }\end{array}$ & $\mathrm{F}$ & Sig. \\
\hline \multirow[t]{3}{*}{1} & $\begin{array}{l}\text { Regress } \\
\text { ion }\end{array}$ & 1710.245 & 2 & 855.123 & $\begin{array}{r}580.8 \\
83 \\
\end{array}$ & $.000^{\mathrm{b}}$ \\
\hline & $\begin{array}{l}\text { Residu } \\
\text { al }\end{array}$ & 142.795 & 97 & 1.472 & & \\
\hline & Total & 1853.040 & 99 & & & \\
\hline \multicolumn{7}{|c|}{ a. Dependent Variable: $\mathrm{Y}$} \\
\hline \multicolumn{7}{|c|}{ b. Predictors: (Constant), X2, X1 } \\
\hline
\end{tabular}

Sumber : Hasil Pengolahan Data SPSS 16 ,diolah peneliti, 2021

Tabel 8 menunjukan bahwa $\mathrm{f}_{\text {hitung }}=580,883$ dan

Sig. $=0.000$. Pengaruh $X_{1}$ dan $X_{2}$ secara simultan terhadap Y diperlihatkan pada tabel 4.55 berikut ini :

Tabel 9 Pengaruh Simultan Kompetensi (X1) dan Pelatihan (X2) Terhadap Kinerja Pegawai (Y)

\begin{tabular}{|c|c|c|c|c|c|}
\hline Struktur & Sig. & $\mathbf{A}$ & $\mathbf{f}_{\text {hitung }}$ & $\mathbf{f}_{\text {tabel }}$ & Kesimpulan \\
\hline $\mathrm{Pyx}_{1}, \mathrm{x}_{2}$ & 0.000 & 0.05 & 580,883 & 3,94 & Ho ditolak \\
\hline
\end{tabular}

Sumber : Data yang diolah peneliti, 2021

Tabel 9 menunjukan bahwa sig. (0.000) $<\alpha(0.05)$ dan $f_{\text {hitung }}(580,883)>\mathrm{f}_{\text {tabel }}(3,94)$, maka $\mathrm{H}_{\mathrm{O}}$ ditolak. Dengan demikian dapat disimpulkan bahwa Kompetensi dan Pelatihan Berpengaruh terhadap Kinerja Pegawai.

\section{KESIMPULAN}

Berdasarkan peneltian yang telah dilakukan maka simpulan yang dapat diambil dari penelitian ini adalah sebagai berikut : a. Hasil rekapitulasi kuesioner Variabel Kompetensi Pegawai menunjukan bahwa pegawai setuju terhadap indikator Kompetensi Pegawai. Namun untuk meningkatkan Kompetensi kerja, masih terdapat indikator yang masih memiliki skor dibawah rata - rata kategori setuju yaitu Indikator Bekerjasama dengan Tim dengan skor 340, Indikator membangun kebersamaan dengan skor 327, dan Indikator Keahlian Teknis dengan skor

b. Hasil rekapitulasi dari kuesioner Variabel Pelatihan Pegawai menunjukan bahwa pegawai setuju terhadap indicator Pelatihan yang dilaksanakan di organisasi. Namun untuk meningkatkan kinerja dari segi keahlian pegawai masih terdapat indicator yang masih memiliki skor dibawah rata-rata kategori setuju yaitu indicator Peningkatan Kinerja dengan skor 360. Indicator Sasaran Jelas dengan skor 360, dan indicator Peningkatan Keterampilan dan Keahlian dengan skor 340.

c. Hasil rekapitulasi dari kuesioner Variabel Kinerja Pegawai menunjukan bahwa pegawai setuju terhadap indikator Kinerja Pegawai. Namun untuk meningkatkan kinerja, masih terdapat indikator yang masih memiliki skor dibawah rata - rata kategori setuju yaitu Indikator keterlambatan dengan skor 353, Indikator komunikasi Antar pegawai, dan Indikator Saling Membantu dengan skor 343.

d. Koefisien korelasi diantara variabel bebas yaitu korelasi antara Kompetensi dengan Pelatihan di dapat nilai 0,864 yang berarti kedua variabel mempunyai hubungan yang Sangat Kuat dan searah karena nilainya positif.

e. Analisis Jalur Variabel Kompetensi secara parsial terhadap Kinerja pegawai adalah sebesar 34,6\% dan Koefisien jalur variabel Pelatihan terhadap Kinerja adalah Sebesar 57,5\%. Dengan demikian dapat disimpulkan bahwa Kompetensi dan Pelatihan memiliki pengaruh parsisal terhadap Kinerja Pegawai.

f. Variabel Kompetensi dan Pelatihan secara simultan mempunyai pengaruh yang positif dan signifikan terhadap Kinerja Pegawai Dinas Tenaga Kerja dan Transmigrasi Kabupaten Karawang. Pengaruh Kompetensi 
dan Pelatihan sebesar 0,921, berarti 92,1\%, variabel Kinerja (Y) bisa diterangkan oleh variabel Kompetensi $\left(\mathrm{X}_{1}\right)$ dan Pelatihan $\left(\mathrm{X}_{2}\right)$ atau dapat diartikan variabel Kompetensi $\left(\mathrm{X}_{1}\right)$ dan Pelatihan $\left(\mathrm{X}_{2}\right)$ memiliki kontribusi terhadap Kinerja Pegawai (Y) sebesar 92,1\%, sedangkan sisanya $7,9 \%$ merupakan kontribusi variabel lain $(\varepsilon)$ yang tidak diteliti.

\section{REFERENSI}

Ataunur, Ilman dan Ariyanto, Eny . 2015. Pengaruh kompetensi dan pelatihan terhadap kinerja karyawan di PT Adaro Energy Tbk. Jurnal penelitian. Magister Manajemen, Universitas Mercu Buana Jakarta. Telaah Bisnis Volume 16, Nomor 2, Desember 2015.

Bintoro, Wahyu Satrio. Sunaryo, Hadi. Dan Anwarodin, M. Khoirul. 2019. Pengaruh kompetensi dan Pelatihan terhadap Kinerja tenaga Medis Puskesmas (Studi Kasus pada Puskesmas Menganti). e Jurnal Riset Manajemen. Fakultas Ekonomi UNISMA.

Diyana, Anissa. 2017. Pengaruh Pelatihan, Kompetensi dan Disiplin Kerja Terhadap Kinerja Karyawan (Studi Pada PT. Eco Smart Garment Indonesia). Skripsi. Fakultas Ekonomi dan Bisnis Islam. Institut Agama Islam Negeri Surakarta.

Dyah Ayu, Anggi. 2014. Pengaruh Komitmen Organisasional dan Disiplin Kerja Terhadap Prestasi Kerja Karyawan (Studi Kasus pada Kryawan Tetap PT. Pabrik Gula Toelangan Sidoarjo). Jurnal: Universitas Brawijaya Malang. Vol. 15, No. 2, 2 Oktober 2014

Jamali, Abdul. 2016. Pengaruh pelatihan dan kompetensi terhadap kinerja karyawan di PT. Sadar Dinamis Sampang. Universitas Madura. Jurnal Manajemen \& Kewirausahaan, Vol. 1 No. 2 | November 2016. EISSN 2549-7308.

Karina, Nadia. 2017. Analisis Pengaruh Kompetensi dan Motivasi Terhadap Kinerja Karyawan PT. PLN Persero Kantor Distribusi Wilayah Lampung. Thesis. Universitas Lampung
Riyadi, Slamet. 2008. Pengaruh Kompensasi Finansial, Gaya Kepemimmpinan, dan Motivasi Kerja terhadap Kinerja Karyawan pada Perusahaan Manufaktur di Jawa Timur. Skripsi. Universitas 17 Agustus 1945.

Safwan, Nadirsyah, Syukriy Abdullah. 2014. Pengaruh Kompetensi dan Motivasi Terhadap Kinerja Pengelolaan Keuangan Daerah Pada Pemerintah Kabupaten Pidie Jaya. Volume 3, Nomor 1.

Setiadi, Rakhmat. 2018. Pengaruh Pelatihan Dan Kompetensi Terhadap Kinerja Karayawan Pada Dinas Cipta Karya Kabupaten Aceh Utara. Skripsi. Universitas terbuka Jakarta.

Suswardji, Edi, Rachmat Hasbullah dan Tresna F. 2012. Hubungan Kompetensi Dan Disiplin Kerja Terhadap Kinerja Tenaga Kependidikan Universitas Singaperbangsa Karawang, Jurnal Manajemen, Volume 09 Nomor 3, hal 787-788.

Wicaksono, Galih. 2020. Pengaruh Kompetensi Dan Pelatihan Terhadap Prestasi Kerja Relawan Pajak Tax Center Universitas Jember. Skripsi. Universitas Jember.

Yuliana. 2017. Pengaruh Kompetensi dan Motivasi kerja terhadap Kinerja Karyawan Perusahaan Pada PT. Haluan Star Logistic. Jurnal Penelitian. Universitas Wacana Krida. Volume 17, nomor 2. 